\title{
Isolation and characterization of six microsatellite loci in the larch budmoth Zeiraphera diniana (Lepidoptera: Tortricidae)
}

\author{
Sophie Delamaire ${ }^{1}$, G. Danny ESSELINK ${ }^{2}$, Leila SAMIEI ${ }^{2,3}$, Claudine COURTIN $^{1}$, Emmanuelle MAGNOUX ${ }^{1}$, \\ JÉRÔME ROUSSELET ${ }^{1}$ and M.J.M. SMULDERS ${ }^{2}$
}

\begin{abstract}
${ }^{1}$ INRA UR0633 Zoologie Forestière Orléans, 2163 Avenue de la Pomme de Pin, 45075 Orléans, France; e-mail: sophiedelamaire@yahoo.fr

${ }^{2}$ Plant Research International, Wageningen UR Plant Breeding, P.O. Box 16, NL-6700 AA Wageningen ${ }^{3}$ Dept. of Horticulture, College of Agriculture and Natural Resources, University of Tehran, Karaj, Iran
\end{abstract}

Key words. Lepidoptera, Tortricidae, Zeiraphera diniana, larch budmoth, microsatellite markers, outbreak

\begin{abstract}
Six microsatellite markers were developed for the larch budmoth Zeiraphera diniana Guénée 1845, using two enrichment protocols. The number of alleles ranged from 3 to 15 per locus and observed heterozygosities ranged from 0.09 to 0.98 for the 69 individuals genotyped. Using these markers significant genetic differentiation between one population from Poland and samples from Alpine populations in France and Switzerland (overall $F_{S T}=0.0298$ ) was detected. However, the two Alpine samples did not differ significantly. These microsatellite markers are valuable tools for studying the population genetics of Zeiraphera diniana.
\end{abstract}

\section{INTRODUCTION}

The larch budmoth, Zeiraphera diniana Guénée 1845 (Lepidoptera: Tortricidae), is a Palaearctic species (Bovey \& Grison, 1975). In the Alps population densities fluctuate dramatically, with an outbreak every eight to ten years, causing spectacular defoliation of large stands of larch (Larix decidua) (Baltensweiler \& Rubli, 1999). The outbreak takes the form of a wave that spreads from the South-Western to North-Eastern Alps over a period of five to six years (Johnson et al., 2004). The temporal and spatial characteristics of this insect make it a good model for studies on population dynamics and genetics. So far, genetic studies have focused on the differentiation between the host races on larch and pine, using allozymes and AFLP's (Emelianov et al., 1995, 2003a, b). Here we develop microsatellite markers to study population genetics in space and time, which will allow us to investigate the demographic processes observed.

\section{MATERIAL AND METHODS}

This paper reports two different microsatellite screening procedures done in two separate laboratories: Plant Research International, The Netherlands and Forest Zoology Research Unit, INRA, France.

\section{First protocol (Plant Research International, The Nether- lands)}

Microsatellite loci were isolated from a genomic DNA library using an enrichment procedure after Karagyozov et al. (1993). Genomic DNA was isolated from the head of a caterpillar of Zeiraphera diniana using the DNeasy Tissue Kit (Qiagen, Venlo, The Netherlands). Five hundred nanograms of genomic DNA were restricted/ligated with $A l u \mathrm{I}, R s a \mathrm{I}$ or HaeIII, pooled and amplified as previously described (Esselink et al., 2003; Schroeder et al., 2009). Microsatellite-containing fragments were selected by hybridization with Hybond $\mathrm{N}^{+}$membranes using separately spotted synthetic oligonucleotides: (TCT) $)_{10}$, $(\mathrm{TGT})_{10},(\mathrm{GAG})_{8},(\mathrm{GTG})_{8},(\mathrm{TGA})_{9},(\mathrm{AGT})_{9},(\mathrm{CGT})_{8},(\mathrm{GCT})_{8}$, $(\mathrm{GCC})_{7},(\mathrm{GT})_{12}$. Fragments were eluted from the membranes with increasing stringencies: (1) $0.5 \times \mathrm{SSC}, 1 \% \mathrm{SDS}$ for $30 \mathrm{~min}$ at $62^{\circ} \mathrm{C},(2) 0.2 \times \mathrm{SSC}, 1 \% \mathrm{SDS}$ for $30 \mathrm{~min}$ at $62^{\circ} \mathrm{C}$, and $(3)$
$0.1 \%$ SDS for $10 \mathrm{~min}$ at $100^{\circ} \mathrm{C}$. Eluted fragments were precipitated and re-amplified. To obtain microsatellites with a high number of repeats and sufficient flanking sequence, fraction 1 was used for trinucleotide motifs with $30 \% \mathrm{CG}$ content, fraction 2 for motifs with $60 \%$ GC and fraction 3 for motif CGG (100\% CG content). For the GT motif fraction 1 was used. Amplified fragments were cloned and for each motif 192 colonies were screened as previously described (van de Wiel et al., 1999). The most abundant trinucleotide repeat was GCT $(11 \%$ positive clones) followed by GCC (6\%), CGT (4\%), and TCT $(0.5 \%)$. For the other motifs no repeats were isolated. In total 13 sequences with a unique repeat were obtained. All sequences were submitted to the EMBL database (FN185943-185953, FN263245). Primer pairs were designed using LASERGENE v8.1 (DNASTAR, Inc., Madison, WI, USA). Reverse primers were PIG-tailed (Brownstein et al., 1996). Using this enrichment, five polymorphic loci (Zd01, Zd02, Zd05, Zd09, and $Z d 16)$ with unambiguously scorable alleles were obtained.

\section{Second protocol (INRA, France)}

Microsatellite loci were isolated following a biotinenrichment protocol modified from Kijas \& Fowler (1994) and Rousselet et al. (2004). Genomic DNA was extracted from 20 caterpillar heads using the DNeasy Tissue Kit (Qiagen). Total DNA was digested with RsaI and the 300-900 bp-long fragments were isolated on a $1 \%$ agarose gel using the Qiaquick Gel Extraction kit (Qiagen). Biotin-labelled oligonucleotides corresponding to microsatellite motifs $(\mathrm{CT})_{10},(\mathrm{GT})_{10},(\mathrm{CG})_{10},(\mathrm{AT})_{10}$, $(\mathrm{AAT})_{7},(\mathrm{GAA})_{7},(\mathrm{AGC})_{7},(\mathrm{AAC})_{7},(\mathrm{TACA})_{5}$, and $(\mathrm{TACC})_{5}$ were hybridized to the modified DNA, and the enrichment was completed using Streptavidine Magnesphere Paramagnetic Particles (Promega, Madison, WI, USA). After re-amplification and cloning, 5623 recombinant clones were screened by PCR using vector primers plus the repeat-specific primer (Rousselet et al., 2004). A total of 269 positive clones were purified using the Wizard Plus SV Miniprep DNA purification System Kit (Promega). Of the 269 clones, 34 different inserts containing microsatellites were found after sequencing. PCR primers were designed for all of them, but only one locus (ZD32; FN185954) 
TABLE 1. Characteristics of 6 polymorphic microsatellite loci from Zeiraphera diniana tested on 69 individuals (23 from France, 23 from Switzerland, and 23 from Poland).

\begin{tabular}{|c|c|c|c|c|c|c|c|c|c|}
\hline Locus & $\begin{array}{c}\text { Accession } \\
\text { No. }\end{array}$ & $\begin{array}{l}\text { Repeat } \\
\text { motif }^{1}\end{array}$ & Primer sequences $\left(5^{\prime}-3^{\prime}\right)$ & $\mathrm{Ta}^{2}$ & $\begin{array}{l}\text { Allele size } \\
\text { range (bp) }\end{array}$ & $\begin{array}{l}\text { No. of } \\
\text { alleles }\end{array}$ & $H_{O}^{3}$ & $H_{E}$ & $F_{I S}$ \\
\hline \multirow[t]{2}{*}{$\overline{\mathrm{Zd} 01}$} & FN185943 & $(\mathrm{CAA})_{5}$ & F (FAM*): TAGTGCCAAC & 55 & $204-231$ & 5 & 0.725 & 0.621 & -0.167 \\
\hline & & & GTTTCGGA & & & & & & \\
\hline \multirow[t]{2}{*}{$\mathrm{Zd} 02$} & FN185944 & $(\mathrm{CGA})_{34-3}$ & F $\left(\mathrm{HEX}^{*}\right):$ TGGTCAGGA & 59 & & 11 & 0.091 & 0.456 & 0.802 \\
\hline & & & GTTTGAACC & & & & & & \\
\hline \multirow[t]{2}{*}{$\mathrm{Zd} 05$} & FN185946 & $(\mathrm{GCT})_{28-10}$ & F (HEX*): CCTCATGCCCTTCCCTCCAG & 55 & & 3 & 0.217 & 00 & -0.085 \\
\hline & & & GTTTATTGC & & & & & & \\
\hline \multirow[t]{2}{*}{ Zd09 } & FN185945 & $(\mathrm{ACC})_{12-3}$ & $\mathrm{~F}\left(\mathrm{NED}^{*}\right)$ : CCCAAGCGC & 55 & & 6 & 0.580 & 0.692 & 0.162 \\
\hline & & & GTTTGTACTG $A$ & & & & & & \\
\hline \multirow[t]{2}{*}{$\mathrm{Zd} 16$} & FN263245 & $(\mathrm{GAT})_{64-34}$ & ${ }_{4} \mathrm{~F}\left(\mathrm{FAM}^{*}\right)$ : TAGATTCCCCGGAACTAATGATCC & 53 & $276-345$ & 15 & 0.986 & 0.716 & -0.377 \\
\hline & & & GTTTAGATCCTTTGGT & & & & & & \\
\hline \multirow[t]{2}{*}{ ZD32 } & FN185954 & $(\mathrm{CA})_{9}$ & F (FAM*): ATGCCTACCTACTTGATGCC & 49 & $181-213$ & 13 & 0.580 & 0.871 & 0.334 \\
\hline & & & R: $\quad$ AGTTTCCATACATTTGACACCTAC & & & & & & \\
\hline
\end{tabular}

${ }^{1}$ minus denotes mismatch; ${ }^{2} \mathrm{Ta}=$ annealing temperature; * fluorescent dyes used; ${ }^{3}$ GENEPOP v3.4 (Raymond \& Rousset, 1995) was used to calculate $H_{O}$ (observed heterozygosity), $H_{E}$ (expected heterozygosity), and $F_{I S}$ (inbreeding coefficient).

was polymorphic (13 alleles detected). In addition, this locus has an insertion/deletion of an " $\mathrm{A}$ " in its microsatellite motif (determined by the sequencing of the different alleles), which was considered as additional information when scoring.

Technical details and accession numbers are given in Table 1. The six loci were amplified in 69 individuals collected in 2006 within the range of the species where outbreaks occur (France, coordinates $45^{\circ} 01^{\prime} \mathrm{N}, 6^{\circ} 33^{\prime} \mathrm{E}$, and Switzerland, coordinates $46^{\circ} 25^{\prime} \mathrm{N}, 9^{\circ} 44^{\prime} \mathrm{E}$ ) and outside this outbreak range (Poland, coordinates $\left.50^{\circ} 24^{\prime} \mathrm{N}, 16^{\circ} 96^{\prime} \mathrm{E}\right)$. The amplifications were done using a 9800 Fast thermal cycler (Applied Biosystems, Foster City, CA, USA) and the RedTaq package (Sigma-Aldrich, Inc., St Louis, MO, USA). The total reaction volume was $10 \mu \mathrm{L}$, containing $10 \mathrm{ng}$ of genomic DNA, $0.4 \mathrm{U}$ of Taq DNA polymerase (Sigma), $1 \mathrm{X}$ buffer $(100 \mathrm{mM}$ Tris $\mathrm{HCl}, \mathrm{pH} 8.3,500 \mathrm{mM} \mathrm{KCl}$, and $0.1 \%$ gelatin), $20 \mathrm{mg} / \mathrm{L}$ of Betain, $250 \mu \mathrm{M}$ of each $\mathrm{dNTP}$, $0.4 \mu \mathrm{M}$ of each primer, and $1.5 \mathrm{mM} \mathrm{MgCl}_{2}$. Twenty percent of the forward primer was 5 ' end-labelled with a fluorescent dye, either 6-FAM (Sigma), HEX (Sigma) or NED (Applied Biosystems). The cycling conditions were $3 \mathrm{~min}$ at $95^{\circ} \mathrm{C}$ followed by 30 cycles of $50 \mathrm{~s}$ at $95^{\circ} \mathrm{C}, 1 \mathrm{~min}$ at annealing temperature (Table 1 ), and $30 \mathrm{~s}$ at $72^{\circ} \mathrm{C}$. The amplified products were detected on an ABI-3100 automatic sequencer and their sizes were estimated using GENESCAN software (Applied Biosystems).

GENEPOP v3.4 (Raymond \& Rousset, 1995) was used to calculate observed and expected heterozygosities, to test for Hardy-Weinberg equilibrium (HWE) deviation and linkage disequilibrium. The presence of null alleles was estimated using MICRO-CHECKER (Van Oosterhout et al., 2004).

\section{RESULTS}

All individuals were successfully amplified for all loci, except two for locus Zd02. The number of alleles per locus ranged from 3 to 15 and observed heterozygosities ranged from 0.091 to 0.985 (Table 1). Zd16 showed an excess of heterozygotes, while $\mathrm{Zd} 02, \mathrm{Zd} 09$, and $\mathrm{Zd} 32$ showed a deficit of heterozygotes $(P<0.05)$. HWE was accepted for $\mathrm{Zd} 01$ and $\mathrm{Zd} 05(P>0.05)$ No linkage disequilibrium was found between loci $(P>0.05)$. Moreover, only one allele occurred in Poland at the locus Zd02. We estimated the presence of null alleles (MICRO-CHECKER, Van Oosterhout et al., 2004) for locus Zd02 (for the French and Swiss populations), locus Zd09 (for the French population), and locus ZD32 (for the French and Swiss populations).
Overall $F_{S T}$ (Fixation index measuring population differentiation; Weir \& Cockerham, 1984) was 0.0298. Pairwise $F_{S T}$ values (averaged across loci) were $0.0535(P<0.05)$ and $0.0428(P<$ $0.05)$ between France and Poland and between Switzerland and Poland, respectively. There was no differentiation between France and Switzerland $\left(F_{S T}=-0.0065, P>0.05\right)$.

\section{DISCUSSION}

Microsatellites are very suitable markers for studying population genetics, given their high variability, their neutrality, codominance, and reproducibility. Unfortunately, it is often difficult to develop them for species of Lepidoptera (Meglécz \& Solignac, 1998; Nève \& Meglécz, 2000; Zhang, 2004; Meglécz et al., 2004; Habel et al., 2008; Schroeder et al., 2009). Next to very low microsatellite cloning efficiencies, often multiple copies of microsatellite sequences exist with similar flanking regions and null alleles are also frequent (Meglécz \& Solignac, 1998; Nève \& Meglécz, 2000; Meglécz et al., 2007; Zhang, 2004; Vila et al., 2009). In this study two different microsatellite screening procedures, processed in two independent laboratories, were used. This resulted in the development of a total of six polymorphic loci. These microsatellite markers will be valuable tools for studies on the population genetics of Zeiraphera diniana.

Departures from Hardy-Weinberg equilibrium were found in our data for four of the microsatellite markers, Zd02, Zd09, and ZD32 with a deficit of heterozygotes, and Zd16 with an excess of heterozygotes. Departures from HWE can be due to strong inbreeding, population subdivision, selection, null alleles or frequent or severe bottlenecks (revised by Selkoe \& Toonen, 2006). MICRO-CHECKER estimated the presence of null alleles in the three markers in which there was a shortage of heterozygotes. The effect of null alleles could be accompanied by bottleneck effects that may be a consequence of the cyclic outbreak dynamics of $Z$. diniana. No linkage disequilibrium was found, meaning that all loci can be considered as independent.

$F_{S T}$ values indicate that these microsatellite markers are suitable for detecting genetic differentiation throughout the distribution range of $Z$. diniana. Indeed, our results showed that the population in Poland, located outside the range in which outbreaks occur, is significantly differentiated from the population in the Alps, where outbreaks occur $\left(F_{S T}=0.0535\right.$ with French Alps; $F_{S T}=0.0428$ with Swiss Alps). The absence of differentia- 
tion between the French and the Swiss Alps is consistent with data obtained using mtDNA, which show a high level of gene flow at the alpine scale (Delamaire et al., in prep).

ACKNOWLEDGEMENTS. This study was financially supported by the Netherlands' Ministry of LNV (KB-01-007-001) and the Commission of the European Community, Network of Excellence Evoltree, 6th Framework Programme contract no. 16322. It does not necessarily reflect its views and in no way anticipates the Commission's future policy in this area. The authors are grateful to W. Baltensweiler, A. Roques, and M. Kosibowicz for collecting samples and to C. Le Metté for precious technical help.

\section{REFERENCES}

Baltensweiler W. \& Rubli D. 1999: Dispersal: an important driving force of the cyclic population dynamics of the larch bud moth, Zeiraphera diniana Gn. Forest Snow Landsc. Res. 74: 3-153.

Bovey P. \& GRISON P. 1975: La tordeuse grise (Zeiraphera diniana Gn) important ravageur des mélézins alpins. Trav. Sci. Parc Nat. Vanoise 6: 115-139.

Brownstein M.L., Carpten J.D. \& Smith J.R. 1996: Modulation of non-templated nucleotide addition by Taq DNA polymerase: primer modifications that facilitate genotyping. BioTechniques 20: 1004-1010.

Emelianov I., Mallet J. \& Baltensweiler W. 1995: Genetic differentiation in Zeiraphera diniana (Lepidoptera: Tortricidae, the larch budmoth): polymorphism, host races or sibling species? Heredity 75: 416-424.

Emelianov I., Simpson F., Narang P. \& Mallet J. 2003a: Host choice promotes reproductive isolation between host races of the larch budmoth Zeiraphera diniana. J. Evol. Biol. 16: 208-218.

Emelianov I., Marec F. \& Mallet J. 2003b: Genomic evidence for divergence with gene flow in host races of the larch budmoth. Proc. R. Soc. Lond. (B) 71: 97-105.

EsSelink G.D., SMULders M.J.M. \& Vosman B. 2003: Identification of cut rose (Rosa hybrida) and rootstock varieties using robust sequence tagged microsatellite markers. Theor. Appl. Genet. 106: 277-286.

Habel J.C., Finger A., Meyer M., Schmitt T. \& Assmann T. 2008: Polymorphic microsatellite loci in the endangered butterfly Lycaena helle (Lepidoptera: Lycaenidae). Eur. J. Entomol. 105: 361-362.

Johnson D., BJøRnStAD O.N. \& LieBhold A.M. 2004: Landscape geometry and travelling waves in the larch budmoth. Ecol. Lett. 7: 967-974.

Karagyozov L., Kalcheva I.D. \& Chapman M. 1993: Construction of random small-insert genomic libraries highly enriched for simple sequence repeats. Nucl. Acid Res. 21: 3911-3912.
KIJAS J.M.H. \& FowLER J.C.S. 1994: Enrichment of microsatellites from the citrus genomic using biotinylated oligonucleotide sequences bound to streptavidin-coated magnetic particles. Biotechniques 16: 657-662.

Meglécz E. \& SolignaC M. 1998: Microsatellite loci for Parnassius mnemosyne (Lepidoptera). Hereditas 128: 179-180.

Meglécz E., Péténian F., Danchin E., Coeur d’Acier A., RasPLUS J.-Y. \& FAURE E. 2004: High similarity between flanking regions of different microsatellites detected within each of two species of Lepidoptera: Parnassius apollo and Euphydryas aurinia. Mol. Ecol. 13: 1693-1700.

Meglécz E., Anderson A., Bourget D., Butcher R., Caldas A., Cassel-Lundhagen A., Coeur D’Acier A., Dawson A.D., Faure N., Fauvelot C., Franck P., Harper G., Keyghobadi N., Kluetsch C., Muthulakshmi M., Nagaraju J., Patt A., Péténian F., Salivain J.F. \& Wilcock H. 2007: Microsatellite flanking region similarities among different loci within insect species. Insect Mol. Biol. 16: 175-185.

NÈve G. \& Meglécz E. 2000: Microsatellite frequencies in different taxa. Trends Ecol. Evol. 15: 376-377.

Raymond M. \& Rousset F. 1995: Genepop (version 1.2): Population genetics software for exact tests and ecumenicism. $J$. Heredity 86: 248-249.

Rousselet J., Magnoux E. \& Kerdelhué C. 2004: Characterization of five microsatellite loci in the pine processionary moth Thaumetopoea pityocampa (Lepidoptera: Notodontidae: Thaumetopoeinae). Mol. Ecol. Note 4: 213-214

Schroeder H., Arens P. \& Smulders M.J.M. 2009: Autosomal and sex-linked microsatellite loci in the green oak leaf roller Tortrix viridana L. (Lepidoptera, Tortricidae). Mol. Ecol. Resour. 9: 809-811.

Selkoe K.A. \& Toonen R.J. 2006: Microsatellites for ecologists: a practical guide to using and evaluating microsatellite markers. Ecol. Lett. 9: 615-629.

Van de Wiel C., Arens P., Vosman B. 1999: Microsatellite retrieval in lettuce (Lactuca sativa L.). Genome 42: 139-149.

Van Oosterhout C., Hutchinson W.F., Wills D.P.M. \& SHIPLEY P. 2004: Micro-checker: Software for identifying and correcting genotyping errors in microsatellite data. Mol. Ecol. Notes 4: 535-538

Vila M., Latasa T., Pino J.J. \& Verhulst G. 2009: Characterization of ten polymorphic microsatellite markers for the endemic Chapman's ringlet, Erebia palarica (Lepidoptera: Nymphalidae). Eur. J. Entomol. 106: 485-490.

WeIR B.S. \& Cockerham C.C. 1984: Estimating $F$-Statistics for the analysis of population structure. Evolution 38: 1358-1370.

ZHANG D. 2004: Lepidopteran microsatellite DNA: redundant but promising. Trends Ecol. Evol. 19: 507-509.

Received December 2, 2009; revised and accepted February 1, 2010 